\title{
DIGESTIVE AND FUNCTIONAL PROPERTIES OF A PARTIALLY HYDROLYZED CASSAVA SOLID WASTE WITH HIGH INSOLUBLE FIBER CONCENTRATION
}

\author{
Dorivaldo da Silva Raupp ${ }^{1 *}$; Danielle Amorim Rosa ${ }^{1}$; Silvia Helena de Paula Marques ${ }^{1}$; David \\ Ariovaldo Banzatto ${ }^{2}$ \\ ${ }^{1}$ UEPG - Depto. de Engenharia de Alimentos - Av. Carlos Cavalcanti, 4748 - Campus Uvaranas - Bloco F-29 - \\ 84030-000 - Ponta Grossa, PR - Brasil. \\ ${ }^{2}$ UNESP/FCAV - Depto. de Ciências Exatas - Campus de Jaboticabal - Rod. Carlos Tonanni, km 5 - 14870-000 - \\ Jaboticabal, SP - Brasil. \\ *Corresponding author 〈raupp@uepg.br>
}

\begin{abstract}
Starch factories generate large amounts of cassava solid waste. A small amount is utilized for animal feed but most of it is discharged with deleterious effects to the envirounment. A edible food with a high content of insoluble dietary fiber (60.9\%), named "partially hidrolyzed cassava waste" (PHCW), was prepared from industrial cassava solid waste by an enzymatic process. PHCW or wheat bran (WB) were fed to model rats and both promoted digestive function effects, but PHCW produced the greatest effect. The insoluble fiber constituent from PHCW (and not the soluble fiber), promoted the greatest fecal bulking, fecal weight and defecation frequency in rats, as compared to WB. Such results indicate that the partially hydrolyzed cassava waste presents digestive function properties which allow it to be used as an adequate source of insoluble dietary fiber in the formulation of functional food for human nutrition.
\end{abstract}

Key words: cassava, dietary fiber, wheat bran, functional food, human nutrition

\section{PROPRIEDADES FUNCIONAIS-DIGESTIVAS DO CONCENTRADO DE FIBRA ALIMENTAR OBTIDO DE MANDIOCA}

\begin{abstract}
RESUMO: As fecularias e polvilheiras produzem grandes quantidades de bagaço de mandioca. A proposta dessa pesquisa consistiu determinar, em ratos modelo, a propriedade funcional-digestiva do produto alimentício bagaço de mandioca hidrolisado $(\mathrm{BMH})$, um concentrado de fibra alimentar $(60,9 \%$, peso seco) que foi obtido a partir do bagaço de mandioca da polvilheira e através de processo de hidrólise enzimática. $\mathrm{O}$ BMH produziu efeitos fisiológicos no trato digestivo dos ratos modelos mais acentuados que os efeitos produzidos pelo farelo de trigo (FT). Foram os componentes insolúveis da fibra alimentar do BMH, e não a fração solúvel, os que mais contribuíram para o maior volume e peso das fezes e, por conseguinte, para o maior número de defecações. Por isso, o BMH pode ser usado como fonte alternativa de fibra alimentar para a formulação de alimentos, principalmente os consumidos por indivíduos com a finalidade de regular ou manter normal a funcionalidade digestiva.

Palavras-chave: mandioca, fibra alimentar, farelo de trigo, alimento funcional, nutrição humana
\end{abstract}

\section{INTRODUCTION}

Cassava processing plants produce not only tapioca starch and "polvilho", a naturally-fermented cassava starch, typical products of Brazil, but also a solid, moist by-product, the cassava solid waste, which represents an environmental problem. Drying cassava waste, to produce bran/rough flour for animal feed is economically unfeasible, because of low market prices (Lima, 1982; Cereda, 1994; Vilpoux \& Cereda, 1995; Raupp et al., 1998; 1999). The nutritional composition of cassava solid waste was determined by Raupp et al. (1999), and its dietary fiber $(43.1 \%$, dry weight) and starch contents $(47.1 \%$, dry weight), as well as the amount yielded (Cereda, 1996), justify the search for processes that would enable a more noble use for this foodstuff.

Dietary fibers present carbohydrates that are not digested by the digestive enzyms in the human body, but some can be hydrolyzed or degraded by natural microflora present especially in the colon. Pectins, mucilages and gums can be completely degraded, while hemicellulose presents a variable degree of degradation, and cellulose is only slightly degraded. The importance of fibers is related to the physiological effect, both for digestive function regulation and for controlling and/or preventing gastrointestinal diseases or related malfunctions, such as constipation, diverticulitis, digestive cancer, cholesterolemia and glycemia. The ability many fibers have to bind 
to toxic compounds has not been sufficiently studied, although it is considered to be the reason for its protective action against gastrointestinal cancer. The role of fibers such as those in some fruit and vegetables as well as in wheat bran in stimulating peristaltic action, is another effect considered protective. Conversely, some products produced and released in the large bowel from the microbial fermentation of dietary fiber constituents have been considered as carcinogenic. Because viscous fibers slow down the food bolus and fecal matter movement, they stimulate the establishment of constipation (Schweizer \& Edwards, 1992; Birkett et al., 1997; Lewis \& Heaton, 1997; Raupp \& Sgarbieri, 1997; Glitso et al., 1998; Kritchevsky, 1998; Rigaud et al., 1998; Sorensen et al., 1998; Wijnands et al., 1999).

Despite the controversy, the beneficial effects of dietary fibers in human health is clearly shown in most research. These results have, in recent years, awakened foodstuff producers for the need of making available feeds containing dietary fibers in their composition. Fibrous byproducts, such as those from wheat mills, are no longer discharged since their use is a well-established practice in human nutrition. A possible exploitation alternative, both for the solid waste from starch factories and for the solid bulky mass that results from its hydrolysis, would be its utilization as ingredient in the formulation of fibrous food products. Therefore, this research was aimed at evaluating, in model rats, the functional digestive properties of a concentrate foodstuff rich in insoluble dietary fiber, the partially hydrolyzed cassava waste (PHCW), which was prepared from cassava solid waste produced by a starch factory, against wheat bran, a dietary fiber standard.

\section{MATERIAL AND METHODS}

The raw material "cassava solid waste", a discharged by-product in starch factories, was collected in factories in the region of Tibagi, Paraná, where it is still considered waste material. The process utilized for obtaining "polvilho" (naturally fermented starch) from cassava, which also yields the discharged "cassava solid waste" is summarized ahead.

The cassava roots are washed and peeled in machines operating under continuous water stream. Dirt and superficial brown peel are eliminated in this first step. Roots are then ground and transformed, into a mass, which is conducted to a vibrating sifting system all under running water. The starch is carried by water to a brusher which compress the cassava mass forward against the gutter walls and the starch-rich water passes through the gutter holes, transporting the starch through of pipes to a cylindrical collector located under the brushing system. The water carries the starch from the cylindrical collector to a maze-shaped tank, where starch settling (sedimentation) occurs.
The surfacing water, referred to as "manipueira", is collected into settling ponds exposed to the environment. The freshly obtained moist starch is transported to a tank for natural fermentation. The mass or cake is then air dried and ground, resulting in the fermented product "polvilho azedo" (sour starch). The discharged material produced in the sifting system and in the brusher constitute the "cassava solid waste".

A concentrate dietary fiber feed, referred to as "partially hydrolyzed cassava waste" (PHCW), was prepared from the cassava solid waste as recommended by Raupp et al. (2002). An enzymatic hydrolysis process was applied to the cassava solid waste, consisting in the use of the amylolytic commercial enzymes termamyl and amyloglucosidase (AMG), for saccharification of the remaining starch. Pectinex, an enzyme that acts on the fibers that make up the cell wall, was also applied to improve the efficiency of the amylolytic hydrolysis process.

The solid matter that resisted the hydrolysis process, after separation from the liquid portion by filtration followed by washing under running water, was dried in circulation oven with the temperature adjusted between 60 and $70^{\circ} \mathrm{C}$ and homogeneized in an industrial blender, resulting in the product specified as "partially hydrolyzed cassava waste" (PHCW).

The rehydration capacity was determined according to Schweizer \& Edwards (1992), while granulometry was determined by sifting a $100 \mathrm{~g}$ sample for 30 minutes in a $2.0-1.0-0.25-0.105-0.059 \mathrm{~mm}$ mesh sieves sequence. The portions retained by each sieve were weighed and their relative proportions in the product were calculated.

The PHCW was incorporated into diets and fed to growing model rats, to evaluate its digestive function properties, food intake, feed conversion ratio (FCR) and operational protein efficiency ratio (PERop). Wheat bran (WB) was used as a fiber source standard. The trial consisted of seven treatments with six rats/treatment, individually housed according to a random block design. Three treatments received PHCW at rates of 5\%, 15\% or $25 \%$ of the diet; three treatments received WB as a comparison standard also at the rates of $5 \%, 15 \%$ or $25 \%$; and one treatment did not receive any source of fiber.

Diets were prepared out of casein provided by Kauffmann \& Co., $90.39 \%$ protein $\left(\% \mathrm{~N}^{\prime} 6.40\right.$; AOAC, 1984), dry basis; refined soybean oil; corn starch (purity degree of $99.8 \%$, dry basis); vitamin mix and mineral mix, both prepared in the laboratory according to the AIN-93G formulation (Reeves et al., 1993). The base diet was prepared according to the AIN-93G formulation (Reeves et al., 1993) to contain: casein $20 \%$; soybean oil $7 \%$; mineral mix $3.5 \%$; vitamin mix $1 \%$; L-cystine $0.3 \%$; choline bitartrate $0.25 \%$. Starch, the only digestible polysaccharide source in the base diet, was utilized q.s. $100 \%$.

Sci. Agric. (Piracicaba, Braz.), v.61, n.3, p.286-291, May/June 2004 
PHCW or the WB standard were added to the base diet as the only source of dietary fiber at $5 \%, 15 \%$ or $25 \%$, as a replacement for equal percentage of starch. The AIN93G formulation (Reeves et al., 1993) provides 5\% fiber in a regular diet, and the fiber constituent in the base diet was replaced with PHCW or with WB (Table 1).

Model animals were 21-day-old "Specific Pathogen Free" (SPF) albino rats, Wistar strain. During the assay, the temperature in the laboratory was maintained at $21 \pm 2{ }^{\circ} \mathrm{C}$, with automatic alternation of 12 hour photoperiods. Diet and water were provided ad libitum. The assay lasted 33 days, including 5 days for adaptation to the experimental environment.

Feces were collected, food intake weight and body weight were determined each other days for each rat. Feces were oven-dried $\left(70^{\circ} \mathrm{C}\right)$, fecal weight and bulk were determined, and the fecal units were counted to determine the number of defecations. Upon determination of body weight and amount of food and protein consumed, feed conversion ratio (FCR) (Sgarbieri, 1987) and the operational protein efficiency ratio (PERop) were calculated, respectively. The FCR value was obtained, by dividing the animal's weight gain $(\mathrm{g})$ by the amount of food consumed during the assay; the PERop value was obtained by dividing the animal's weight difference $(\mathrm{g})$ by the amount of protein ingested during the assay. The amount of protein was quantified by Kjeldhal methodology and the 6.40 factor was utilized to convert the nitrogen percentages into protein (AOAC, 1984).

Data were submitted to analysis of variance and treatment means were compared by Tukey test $(P=0.05)$, according to Banzatto \& Kronka (1995). Data were also evaluated by polynomial regression analysis to fit a statistical function relating the characteristics (variables) as a function of rates of dietary fiber sources utilized in the diets, (Banzatto \& Kronka, 1995).

\section{RESULTS AND DISCUSSION}

The interferences of PHCW in defecation frequency, weight and bulk of feces produced by the rats are shown in Table 2. Diets containing either PHCW or WB stimulated the animals' digestive tract function, as compared to the base diet (without a FS).

The incorporation of $5 \%, 15 \%$ or $25 \%$ of $\mathrm{PHCW}$ or WB to the base diet resulted in higher no. of defecations, weight and bulk of dry feces produced by the animals. Only the group receiving the diet containing 5\% WB did not differ from the group receiving the base diet with regard to the no. of defecations (Table 2).

The polynomial regression analysis showed that there is a high degree of fitting, according to a linear re-

Table 1 - Composition (dry basis) ${ }^{1}$ of dietary fiber sources utilized in the formulation of diets to feed model rats.

\begin{tabular}{|c|c|c|c|c|c|}
\hline Fiber source & Dietary fiber & Digestible carbohydrate $^{4}$ & Protein & Lipid & Ash \\
\hline & 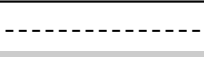 & - $\%$ & $-\cdots$ & - & $-\cdots$ \\
\hline Partially hydrolyzed cassava waste $(\mathrm{PHCW})^{2}$ & 60.9 & 24.6 & 4.7 & 0.7 & 2.2 \\
\hline Wheat bran $(\mathrm{WB})^{3}$ & 37.7 & 24.7 & 17.6 & 3.0 & 5.6 \\
\hline
\end{tabular}

Table 2 - Mean values of treatments and results from Tukey test between means, for variables measured in a 28-day biological assay with rats.

\begin{tabular}{|c|c|c|c|c|c|c|c|c|}
\hline \multirow{3}{*}{ Variables } & \multicolumn{8}{|c|}{ Treatment } \\
\hline & \multicolumn{2}{|c|}{0} & \multicolumn{2}{|r|}{5} & \multicolumn{2}{|c|}{15} & \multirow{2}{*}{$\begin{array}{c}25 \\
\mathrm{WB} \\
\end{array}$} & \multirow[t]{2}{*}{$\mathrm{cv}$} \\
\hline & Without FS & PHCW & WB & PHCW & WB & PHCW & & \\
\hline & $-\ldots-n-1-1$ & - & 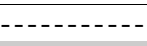 & 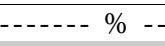 & (n-1) & $-\cdots-1-1$ & $-\ldots-n$ & $-\cdots-$ \\
\hline $\begin{array}{l}\text { No. of defecations per } 100 \mathrm{~g} \\
\text { ingestion }\end{array}$ & $116.6 \mathrm{f}$ & $181.4 \mathrm{de}$ & 145.0 ef & $343.4 \mathrm{~b}$ & $208.7 \mathrm{~d}$ & $482.2 \mathrm{a}$ & $280.3 \mathrm{c}$ & 13.24 \\
\hline $\begin{array}{l}\text { Weight of dry feces per } 100 \mathrm{~g} \\
\text { ingestion }(\mathrm{g})\end{array}$ & $3.6 \mathrm{~g}$ & $7.0 \mathrm{e}$ & $5.6 \mathrm{f}$ & $15.0 \mathrm{~b}$ & $9.1 \mathrm{~d}$ & $21.9 \mathrm{a}$ & $13.2 \mathrm{c}$ & 6.07 \\
\hline $\begin{array}{l}\text { Bulk of dry feces per } 100 \mathrm{~g} \\
\text { ingestion }(\mathrm{mL})\end{array}$ & $4.4 \mathrm{e}$ & $16.5 \mathrm{c}$ & $10.2 \mathrm{~d}$ & $35.4 \mathrm{~b}$ & $18.4 \mathrm{c}$ & 67.6 a & $33.6 \mathrm{~b}$ & 9.97 \\
\hline $\begin{array}{l}\text { Food intake during 28-day assay } \\
(\mathrm{g})\end{array}$ & $338.4 \mathrm{a}$ & $394.8 \mathrm{a}$ & 384.7 a & $413.4 \mathrm{a}$ & $377.0 \mathrm{a}$ & $412.6 \mathrm{a}$ & $339.7 \mathrm{a}$ & 11.52 \\
\hline $\begin{array}{l}\text { Body weight gain during 28-day } \\
\text { assay (g) }\end{array}$ & $114.2 \mathrm{a}$ & 148.9 a & $143.4 \mathrm{a}$ & $137.4 \mathrm{a}$ & $139.0 \mathrm{a}$ & $119.3 \mathrm{a}$ & $114.5 \mathrm{a}$ & 20.56 \\
\hline Feed conversion ratio (FCR) & $0.33 \mathrm{ab}$ & $0.38 \mathrm{a}$ & $0.38 \mathrm{a}$ & $0.33 \mathrm{ab}$ & $0.37 \mathrm{ab}$ & $0.29 \mathrm{~b}$ & $0.32 \mathrm{ab}$ & 13.24 \\
\hline $\begin{array}{l}\text { Operational protein efficiency } \\
\text { ratio (PERop) }\end{array}$ & $1.86 \mathrm{ab}$ & $2.20 \mathrm{ab}$ & $2.30 \mathrm{a}$ & $1.94 \mathrm{ab}$ & $2.13 \mathrm{ab}$ & $1.67 \mathrm{~b}$ & $1.92 \mathrm{ab}$ & 14.77 \\
\hline
\end{tabular}

Values in the rows showing distinct letters differ $(P<0.05)$; Without FS = without a fiber source; PHCW = partially hydrolyzed cassava waste; WB = commercially obtained wheat bran (standard); $\mathrm{cv}=$ coefficient of variation. 
gression model, both for the treatment containing PHCW and for the treatment containing WB, for the dependent variables: no. of defecations per 100g ingestion (PHCW: $\mathrm{Y}=113.94+14.84 \mathrm{X}, \mathrm{r}^{2}=0.9987 ; \mathrm{WB}: \mathrm{Y}=113.86+$ $\left.6.56 \mathrm{X}, \mathrm{r}^{2}=0.9982\right)$; weight of dry feces per $100 \mathrm{~g}$ ingestion (PHCW: $\mathrm{Y}=3.56+0.74 \mathrm{X}, \mathrm{r}^{2}=0.9988 ; \mathrm{WB}$ : $\mathrm{Y}$ $\left.=3.66+0.38 \mathrm{X}, \mathrm{r}^{2}=0.9991\right)$; and, bulk of dry feces per $100 \mathrm{~g}$ ingestion (PHCW: $\mathrm{Y}=3.20+2.47 \mathrm{X}, \mathrm{r}^{2}=0.9855$; WB: $\left.\mathrm{Y}=3.88+1.13 \mathrm{X}, \mathrm{r}^{2}=0.9816\right)$. There was a linear correlation between rate $(5 \%, 15 \%, 25 \%)$ of the fiber source $\mathrm{PHCW}$ or $\mathrm{WB}$, and each of the dependent variables under study.

In general, PHCW produced more pronounced effects than WB on variables no. of defecations, weight and bulk of dry feces (Table 2). At the rates of 5\%, 15\% or $25 \%$ of the PHCW or WB, values for weight and bulk of dry feces produced per $100 \mathrm{~g}$ ingestion were higher for PHCW. With regard to the no. of defecations per 100 $\mathrm{g}$ ingestion, values were also higher for PHCW at the $15 \%$ or $25 \%$ rates. However, at the $5 \%$ rate there was no difference between PHCW and WB.

PHCW presented 1.6 times the content of dietary fiber in the WB (60.9\% against $37.7 \%$ ), and a similar proportion of digestible carbohydrate (24.6\% against $24.7 \%$ ). However, it showed about one fourth of protein $(4.7 \%$ against $17.5 \%)$ and lipid (0.7\% against $3.0 \%)$ and $40 \%$ of the ash content (2.2\% against 5.6\%) (Table 1, Raupp et al., 2002).

The bulk and weight of feces, as well as the number of defecations, produced by rats receiving PHCW were higher, as compared with those produced by rats that received WB (Table 2), probably, because the PHCW source had 1.6-fold greater content of dietary fiber than WB standard (Table 1, Raupp et al., 2002). Therefore, considering the proportion of dietary fiber (dry weight) equal to $60.9 \%$ for PHCW and $37.7 \%$ for WB (Table 1, Raupp et al., 2002), diets that received PHCW showed fiber contents of PHCW diets were $3.0 \%, 9.1 \%$ or $15.2 \%$, while diets and fiber contents of WB diets were $1.9 \%$, $5.6 \%$ or $9.4 \%$, respectively, for diets containing fiber source rates of $5 \%, 15 \%$ or $25 \%$.

Another explanation for these results is that PHCW fiber source presented greater degree of hydration than WB (Table 3) under agitation a condition that occurs in the rat's digestive tract. In addition, because of the process by which it was obtained the dietary fiber in the PHCW, consisted basically of insoluble fiber (Table 1; Raupp et al., 2002), which is a low-viscosity, structural fiber, not hydrolyzed by the digestive juices until it reaches the small bowel, and is subject to very little degradation by the fermentable bacteria that typically occur in the large bowel flora of rats.

Two groups - 15\% PHCW and 25\% WB - (Table 2 ), received diets containing similar amounts of dietary fiber respectively $9.1 \%$ and $9.4 \%$. The group treated with
Table 3 - Degree of hydration ${ }^{1}$, with and without agitation, of dietary fiber sources utilized in the formulation of diets for rats.

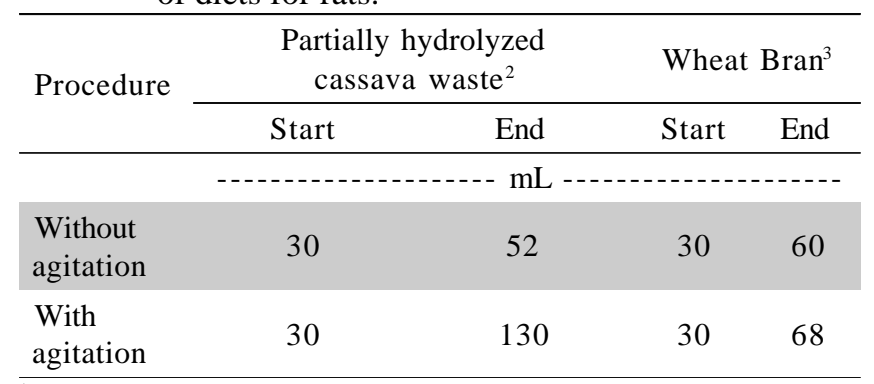

${ }^{1}$ mean of three analytical determinations, utilizing a $100 \mathrm{~g}$ sample; ${ }^{2}$ solid matter remaining after hydrolysis; ${ }^{3}$ commercially obtained.

PHCW produced a greater no. of defecations and dry feces weight than the WB group. The greater degree of hydration as well as the high proportion of insoluble fiber constituent of PHCW (Table 3), (Table 1; Raupp et al., 2002), which is very little degraded in the rat's digestive tract, explain these results.

In a previous research (Raupp et al., 1999), a mealy product, special cassava meal, was prepared from cassava solid waste produced by a starch factory, and suggested to be used in human nutrition as a potential source of dietary fiber because it had a digestive physiological function typical of insoluble dietary fibers. More recently, Raupp et al. (2002) submitted cassava solid waste from a starch factory to enzymatic hydrolysis by amylolytic enzymes and produced a product the partially hydrolyzed cassava waste (PHCW). The enzymatic hydrolysis process applied removed $69.13 \%$ dry weight from the cassava solid waste, and $30.87 \%$ were resistant to hydrolysis, constituting the PHCW.

A lower proportion of insoluble dietary fiber $43.1 \%$, dry weight (Raupp et al., 1999) - was determined for the cassava solid waste material from the starch factory, while for PHCW the proportion was $60.9 \%$ dry weight, (Table 1; Raupp et al., 2002) Digestible carbohydrates, starch being the main component, represented $47.1 \%$ (dry weight) of the cassava solid waste from the starch factory (Raupp et al., 1999), almost twice the proportion determined for PHCW, which was $24.6 \%$ (Table 1, Raupp et al., 2002). Therefore, the enzymatic hydrolysis applied by Raupp et al. (2002) to the cassava solid waste from the starch factory caused a reduction in digestible carbohydrates in the PHCW, but concentrated the dietary fiber constituent.

Leonel (1998) characterized a solid product also prepared by enzymatic hydrolysis followed by filter pressing, from cassava bran produced by a starch factory, and obtained the following results: $0.5 \%$ ash, $38 \%$ total sugars, only $18 \%$ fiber, with $39 \%$ residual starch remaining in it. Cereda (1996) also found $75.0 \%$ starch and $11.5 \%$ fiber in the bran, another designation of the cassava solid waste. 
Differences found in distinct papers for fiber can be attributed in part to the application of different analytical techniques. Cereda (1996) and Leonel (1998) used the chemical hydrolysis analytical technique for crude fiber determination, while Raupp et al. (1999; 2002) used the enzymatic technique, according to Prosky et al. (1988), to determine dietary fiber.

Granulometry (Table 4), and especially the high concentration of dietary fiber (Table 1; Raupp et al., 2002) could explain the higher degree of hydration (Table 3) of PHCW, as compared to WB, when both fiber sources remained submersed in water under agitation. Under agitation, PHCW increased dry volume 4.3 times, while WB increased its dry volume 2.2 times. However, without agitation, i.e., when the products remained in contact with static water, the WB showed hydration capacity just slightly higher (2-fold WB against 1.7-fold for PHCW). These properties apparently influenced the digestive function variables measured in model rats during the biological assays.

The ingestion of insoluble fiber increases body weight and fecal bulking, as well as frequency defecations, both in model animals and in humans, as shown by Walker (1975), Eastwood et al. (1984), Schneemann (1987), Seva-Pereira et al. (1991), Schweizer \& Edwards (1992), Saura Calixto (1993), Raupp \& Sgarbieri (1996; 1997), Raupp et al. (1999; 2000), as a result of the normalization of the digestive function. However, Raupp \& Sgarbieri (1997) studied the nutritional and physiological-digestive effect of a high-viscosity soluble fiber in model rats and demonstrated that this fiber produced, in contrast, feces with much smaller weight and bulk. The frequency with which the animals defecated was also smaller, comparatively to the purified cellulose insoluble fiber. The authors postulated that the normalization of digestive function by fibers comes from their hydration ability and the formation or not of bulky chemical structures, as well as to their fermentability property, related to the bulk and weight of the feces, and also because being the result of food bolus and fecal matter movement, they consequently influence the frequency of defecations. In ad-

Table 4 - Granulometry $(\mathrm{w} / \mathrm{w})^{1}$ of dietary fiber sources utilized in the formulation of diets for rats.

\begin{tabular}{lcc}
\hline Size of particles & $\begin{array}{c}\text { Partially hydrolyzed } \\
\text { cassava waste }\end{array}$ & Wheat Bran $^{3}$ \\
\hline $\mathrm{mm}$ & 0.00 & 0.00 \\
$>2.0$ & 3.66 & 0.38 \\
2.0 to 1.0 & 74.96 & 61.80 \\
1.0 to 0.25 & 15.63 & 35.83 \\
0.25 to 0.105 & 3.66 & 1.10 \\
0.105 to 0.059 & 2.09 & 0.89 \\
$<0.059$ & & 0.09
\end{tabular}

${ }^{1}$ mean of three analytical determinations, utilizing a $100 \mathrm{~g}$ sample; ${ }^{2}$ solid matter remaining after hydrolysis; ${ }^{3}$ commercially obtained. dition, the suggested ingestion of dietary fibers is $25-35$ g per day (Schweizer \& Edwards, 1992).

With respect to the nutritional variables measured during the 28 days of experimentation - food intake, body weight gain, feed conversion ratio (FCR) and operational protein efficiency ratio (PERop) (Table 2) - there were no differences between the PHCW and $\mathrm{WB}$ at all rates. No linear correlations were observed between rate $(5 \%$, $15 \%, 25 \%$ ) of fiber sources (PHCW or WB) and the dependent variables food intake, body weight gain, FCR and PERop. The ingestion of more fiber did not stimulate the rats to ingest more food and did not result in weight gain, FCR and PERop increases.

Similar results were obtained by Raupp et al. (2000), studying refined apple pulp, a dehydrated product as fiber source to model rats. In addition according to Raupp \& Sgarbieri (1996), the addition of 3\%, 6\% or 9\% insoluble fiber (cellulose) to the diet of rats at stimulated food ingestion, but did not significantly affect the rats' weight. However, the high-viscosity soluble fiber (Raupp \& Sgarbieri, 1997) extracted from 80 SH carioca bean decreased diet ingestion and negatively affected the rats' weight gain. Reductions in body weight were also observed by Mikkelsen et al. (1979) and Krotkiewski (1984) in humans and rats fed cellulose and guar gum, respectively, and also by Davies et al. (1991), who fed rats with diets containing purified fibers, either pectin or cellulose. Increase in satiety and reduction in food ingestion were also observed by Bolton et al. (1981) as a function of dietary fibers from several sources.

The addition of PHCW as a fiber source to the diet produced, in the rats' digestive tract effects that would be attributable to a dietary fiber that is little degraded by the intestinal fermentative flora in these animals. The insoluble dietary fiber components that were part of the PHCW source (and not its soluble fraction) contributed the most toward greater feces bulking and weight, and therefore to a greater number of defecations. PHCW shows as potential, alternative source of dietary fiber for the formulation of feeds for a normal human diet, and especially for the formulation of special feeds, consumed by groups of individuals aiming to maintain or normalize digestive tract function.

\section{ACKNOWLEDGEMENTS}

The first author thanks CNPq/PIBIC-UEPG for granting an undergraduate research scholarship from Aug/ 99 - Jul/00; Santa Rosa Starch Factory, Tibagi-PR for providing the cassava solid waste material; Novo Nordisk Bioindustrial do Brasil Ltda, Araucária-PR, for donating the enzymes; UFSC for providing the rats and for allowing the biological assays to be performed; the technicians at Laboratório de Tecnologia de Sementes-UEPG, for support. 


\section{REFERENCES}

ASSOCIATION OF OFFICIAL ANALYTICAL CHEMISTS. Official methods of analysis. 14.ed. Washington: AOAC, 1984.

BANZATTO, D.A.; KRONKA, S.N. Experimentação agrícola. 3.ed. Jaboticabal: FUNEP; UNESP; FCAV, 1995. 247p.

BIRKETT, A.M.; JONES, G.P.; DE SILVA, A.M.; YOUNG, G.P.; MUIR, J.G. Dietary intake and faecal excretion of carbohydrate by Australians: importance of achieving stool weights greater than $150 \mathrm{~g}$ to improve faecal markers relevant to colon cancer risk. European Journal of Clinical Nutrition, v.51, p.625-632, 1997.

BOLTON, P.R.; HEATON, K.W.; BURROUGHS, L.F. The role of dietary fiber in satiety, glucose, and insulin: studies with fruit and fruit juice. Journal of Clinical Nutrition, v.34, p.211-217, 1981.

CEREDA, M.P. Resíduos da industrialização da mandioca no Brasil. São Paulo: Paulicéia, 1994. 100p.

CEREDA, M.P. Caracterização, uso e tratamento de resíduos da industrialização da mandioca. Botucatu: Centro de Raízes Tropicais, 1996. 56p.

DAVIES, J.R.; BROWN J.C.; LIVESEY, G. Energy values and energy balance in rats fed on suplements of guar gum or cellulose. British Journal of Nutrition, v.65, p.415-433, 1991.

EASTWOOD, M.A.; BRYDON, W.G.; BAIARD, J.D.; ELTON. R.A.; HELLIWELL, S.; SMITH, J.H.; PRITCHARD, J.L. Faecal weight and composition, serum lipids, and diet among subjects age 18 to years not seeking health care. American Journal of Clinical Nutrition, v.40, p.628-634, 1984.

GLITSO, L.V.; BRUNSGAARD, G.; HOJSGAARD, S.; SANDSTROM, B.; BACH KNUDSEN, K.E. Intestinal degradation in pigs of rye dietary fibre with different structural characteristics. British Journal of Nutrition, v.80, p.457-468, 1998.

KRITCHEVSKY, D. Cereal fibres and colorectal cancer: a search for mechanisms. European Journal of Cancer Prevention, v.7, p.33-39, 1998.

KROTKIEWSKI, M. Effect of guar-gum on body weight, hunger ratings and metabolism in obese subjects. British Journal of Nutrition, v.52, p.97-105, 1984.

LEONEL, M. Uso de enzimas complementares na produção de etanol a partir de farelo de mandioca. Botucatu: UNESP/FCAV, 1998. 116p. (Tese - Doutorado).

LEWIS, S.J.; HEATON, K.W. Increasing butyrate concentration in the distal colon by accelerating intestinal transit. Gut, v.41, p.245-251, 1997.

LIMA, U.A. Beneficiamento e industrialização da mandioca. São Paulo: Secretaria da Indústria e Comércio, Ciência e Tecnologia, 1982.

MIKKELSEN, O.; MAKDANI, D.D.; COTTON, R.H.; TITCOMB, S.T.; COLMEY, J.C.; GATTY, R. Effects of a high fiber bread diet on weightloss in college-age males. American Journal of Clinical Nutrition, v.32, p.1703-1709, 1979.

PROSKY, L.; ASP, N-G.; SCHWEIZER, T.F.; DeVRIES, J.W.; FURDA, I. Determination of insoluble, soluble and total dietary fiber in foods and food products: Inter-laboratory study. Journal of the AOAC, v.71, p.1017-1023, 1988

RAUPP, D.S.; SGARBIERI, V.C. Efeitos de frações fibrosas extraídas de feijão (Phaseolus vulgaris, L.) na utilização de macro e micronutrientes da dieta pelo rato. Ciência e Tecnologia de Alimentos, v.16, p.100107, 1996.

RAUPP, D.S.; SGARBIERI, V.C. Efeito da fibra solúvel de alta viscosidade na ingestão de alimentos, na excreção fecal e no peso corpóreo, em ratos. Brazilian Archives of Biology and Technology, v.40, p.863-874, 1997.
RAUPP, D.S.; MOREIRA, S.S.; BANZATTO, D.A.; WOSIACKI, G.; SGARBIERI, V.C. Farinha de mandioca lite: industrialização potencial a partir de polpa de mandioca residual produzida como descarte pela polvilheira. In: CONGRESSO BRASILEIRO DE CIÊNCIA E TECNOLOGIA DE ALIMENTOS, 16., Rio de Janeiro, 1998. Anais. Rio de Janeiro: SBCTA, 1998. p.374.

RAUPP, D.S.; MOREIRA, S.S.; BANZATTO, D.A.; SGARBIERI, V.C. Composição e propriedades fisiológico-nutritivas de uma farinha rica em fibra insolúvel obtida do resíduo fibroso de fécula de mandioca. Ciência e Tecnologia de Alimentos, v.19, p.205-210, 1999.

RAUPP, D.S.; CARRIJO, K.C.R.; COSTA, L.L.F.; MENDES, S.D.C.; BANZATTO, D.A. Propriedades funcionais-digestivas e nutricionais de polpa-refinada de maçã. Scientia Agricola, v.57, p.395-402, 2000

RAUPP, D.S.; MARQUES, S.H.P.; ROSA, D.A.; CALDI, C.M.; CREMASCO, A.C.V.; BANZATTO, D.A. Arraste via fecal de nutrientes da ingestão produzido por bagaço de mandioca hidrolisado. Scientia Agricola, v.59, p.235-242, 2002.

REEVES, P.G.; NIELSEN, F.H.; FAHEY JR., G.C. AIN-93 Purified diets for laboratory rodents: final report of the American Institute of Nutrition Ad Hoc Writing Committee on the reformulation of the ain- $76^{\mathrm{A}}$ rodent diet. The Journal of Nutrition, v.123, p.1939-1951, 1993.

RIGAUD, D.; PAYCHA, F.; MEULEMANS, A.; MERROUCHE, M.; MIGNON, M. Effect of psyllium on gastric emptying, hunger feeling and food intake in normal volunteers: a double blind study. European Journal of Clinical Nutrition, v.52, p.239-245, 1998.

SAURA CALIXTO, F. Fibra dietetica de manzana: Hacia nuevos tipos de fibras de alta calidad. Alimentaria, v.5, p.57-61, 1993

SCHNEEMANN, B.O. Soluble vs insoluble fiber: different physiological responses. Food Technology, v.2, p.81-82, 1987.

SCHWEIZER, T.F.; EDWARDS, C.A. Dietary fibre: a component of food; nutritional function in health and disease. London: Springer-Verlag, 1992. $354 \mathrm{p}$.

SEVA-PEREIRA, A.; MORAES, G.R.; OLIVEIRA, S.P.; REYES, F.G.R Uso de biscoito rico em fibras no tratamento da constipação intestinal crônica. Revista Paulista de Medicina, v.109, p.265-268, 1991.

SGARBIERI, V.C. Alimentação e nutrição: fator de saúde e desenvolvimento. Campinas: ALMED; UNICAMP, 1987. 387p.

SORENSEN, I.K.; KRISTIANSEN, E.; MORTENSEN, A.; NICOLAISEN, G.M.; WIJNANDS, J.A.; VAN KRANEN, H.J.; VAN KREIJL, C.F. The effect of soy isoflavones on the development of intestinal neoplasia in ApcMin mouse. Cancer Lett, v.14, p.217-225, 1998.

VILPOUX, O.; CEREDA, M.P. Caracterização das fecularias do Brasil. Botucatu: Centro de Raízes Tropicais, 1995. 58p.

WALKER, A.R.P. Effect of high crude fiber intake on transit time and the absorption of nutrients in South African Negro schoolchildren, American Journal of Clinical Nutrition, v.28, p.1161-1169, 1975

WIJNANDS, M.V.; APPEL, M.J.; HOLLANDERS, V.M.; WOUTERSEN, R.A. A comparison of the effects of dietary cellulose and fermentable galacto-oligosaccharide, in a rat model of colorectal carcinogenesis: fermentable fibre confers greater protection than non-fermentable fibre in both high and low fat backgrounds. Carcinogenesis, v.20, p.651656,1999

Received October 04, 2003

Accepted March 15, 2004 